\title{
LEVEL OF KNOWLEDGE OF SENIOR HIGH SCHOOL STUDENTS TO MANGROVE CONSERVATION
}

\author{
Fahmi Arif Kurnianto ${ }^{1}$, Bejo Apriyanto ${ }^{1}$, Elan Artono Nurdin ${ }^{1}$, Fahrudi Ahwan Ikhsan $^{1}$ \\ ${ }^{1}$ Departement of Geography Education \\ University of Jember, Indonesia \\ E-mail: fahmiarif.fkip@unej.ac.id
}

DOI: $10.19184 /$ geosi.v1i1.6190

\begin{abstract}
Article Info: Received Date $27^{\text {th }}$ November 2017, Received in revised from date $4^{\text {th }}$ December 2017, Accepted Date $7^{\text {th }}$ December 2017, Publish Date 14 ${ }^{\text {th }}$ December 2017
\end{abstract}

\begin{abstract}
Geography Learning in XI Social Science Classes still dominated by conventional teaching methods that make students become unmotivated in learning. Therefore, it is necessary to apply a model of learning that can foster activity and student's level of knowledge. The Group Investigation Learning model (GI) has several advantages. Advantages of Group Investigation Learning model among others: (1) increase the ability to think critically, (2) creating a learning environment that is democratic, (3) enhance the development of soft skills, (4) may improve social solidarity, dan (5) improve student's level of knowledge to learn. The purpose of this study to analyze the influence of group investigation learning model towards the level of mangrove knowledge of students in senior high school. The type of research is the quasi-experimental study with non equivalent control group posttest only design. The subject of the study consisted of class XI Social Science are selected based on the score of Middle Semester Exam (UTS) 2 on 2014-2015 teachings year that had an average of almost the same (homogeneous). The results of this study are showed significant influence of GI models on Geography level of knowledge to learn of students. It was based on the results of the Independent Sample T-Test analysis showed a p-value of 0.000 level. Plevel value is smaller than 0.05 ( $\mathrm{p}<0.05$ ). The average score student's level of knowledge to learn geography experimental class is higher with a score of 208, while the control class $w$ ith a score of 177. That's because the investigations conducted the mangrove forest, teachers simply deliver early learning problems, frequent interaction between students during learning, and students investigate different sub-themes.
\end{abstract}

Keywords: Group Investigation Learning, Level of knowledge, mangrove

\section{INTRODUCTION}

The low ability of students to write the article above needs to be found a solution so that in the future the teacher can take anticipatory measures improve the skills of students writing articles. This is important to do immediately writing articles trains students to think critically for logical (strong) reasons. According to Sanjaya (2006: 78), "One of the factors 
causing low language skills Indonesian students, especially in written language, are because teachers tend to apply conventional learning. "Conventional learning in the application of teachers is moreactive, while students are passive that is only accepting the lessons given teacher.

The negative impact of conventional learning is that students are less motivated learning. According to Kosasih (2007: 35), "Motivation is the driving force which determines the direction of action towards the goal to be achieved motivation for students to learn more actively. Maybe so far students are less motivated to learn because the learning applied by the teacher to students is boring (lecture method accompanied by writing on the board.) Learning needs to be done for that innovative that is motivating students to learn, namely applying the model

Group Investigation learning Mushodik study (2013) found that "model Group Investigation affect the critical thinking skills of students of Madrasah Aliyah Negeri 6 Jakarta". The study has similarities and differences with this research. Similarities with this study that the use of mo dels GI and material conservation of the environment (class XI), while the difference of this study to measure the students' level of knowledge to learn geography, and research Mushodik measure critical thinking skills. The research findings Ulfah (2014) "learning model Group Investigation influence on student learning outcomes SMAN 1 Banjarbaru". The study has similarities and differences with this research. Similarities with this study is the use of the model Group Investigation, while others study the difference between this measure and the level of knowledge to learn geography students study geography Ulfah measure student learning outcomes. The use of GI models by utilizing mangrove forest in the village of Mojo as a Source of Learning is done on the basis of competence to analyze the preservation of the environment in relation to sustainable development (environmental preservation material). Level of knowledge of students is expected to increase with the learning. This is supported by the opinion Sharan (2014: 130) wrote that "GI has a unique character on the integration of the four basic features such as: investigation, interaction, interpretation, and intrinsic level of knowledge". Based on the above problems, the researchers plan to conduct a study entitled "Effect of Model Group Investigation Level of knowledge High School Students Studying Geography".

\section{METHODS}

This type of research that is quasi-experimental design with non equivalentcontrol group posttest only. The following designs were used in this study. 


\begin{tabular}{ccc}
\hline Experimental Group & $\mathrm{X}$ & $\mathrm{O} 1$ \\
\hline Control Group & - & $\mathrm{O} 2$ \\
\hline
\end{tabular}

(Jacksen, 2011:153)

Description :

$\mathrm{X}=$ Learning using a model Group Investigation

- = Learning using a lecture and discussion

$\mathrm{O} 1=$ Charging a queisioner in experimental class

$\mathrm{O} 2=$ Charging a queisioner in control class

\section{RESULTS AND DISCUSSION}

The findings in this study indicate that the model group investigation significant effect on students' level of knowledge to learn geography SMA.hasil calculation t-test with SPSS 16.0 the value of the P-value for the t-test is 0,000 (Appendix 13). Judging from the level of $95 \%$, the figure is less than $0.05 \mathrm{Sig}$.

Other findings in this study include: (1) The students look happy to observe the mangrove forest in the village of Mojo, (2) Students embarrassed to ask, be more frequently asked, especially to the friends group of their, (3) Students feel more challenged by the the task of formulating the questions given by the teacher, (4) Sub different themes makes the curiosity of students is high.

Additional findings in this study include group work seriously because their work will be evaluated by other groups and all the students are more active in learning. This was caused by investigations conducted outside of school, the teacher only spoke about the problems in early learning, and frequent interaction between students during the learning. These three factors that make learning GI different from other cooperative learning.

The results showed that the model group investigation significant effect on high school students' level of knowledge to learn geography. This is evidenced by the hypothesis test. Hypothesis test results show P-value for the t-test of $0.000(0.000<0.05)$. The average value of the experimental class level of knowledge for 208, while the average value of level of knowledge control class is 177 . The results are in accordance with the opinion of Sharan 
(134: 2014) "investigation group to motivate students to take an active role in determining what they learned and how they study".

The results also supported by the results of previous studies, including research conducted by Tan (2004). The equation of this study with previous research the models GI effect on students' level of knowledge to learn geography. The research also has differences with previous studies. This study uses a class XI IPS SMA as a research subject, whereas previous studies using class VIII SMP as a research subject. This study learning material that is the preservation of the environment, while learning materials in research Tan namely natural resources.

Research results Yulianto et al (2013) supports these results. Et al Yulianto research results obtained GI cooperative learning inquiry-based experiments effect on students' level of knowledge. Equation Yulianto research colleagues with this study lies in the model of GI effect on students' level of knowledge. The study also has differences with this research. Yulianto research subjects and others that junior high school students of class VIII, while the subject of this research the high school students of class XI. This study learning material that is the preservation of the environment, while learning material on Yulianto et al study the refraction of light (physics).

Research results Widiarsa et al (2014) also supports this research. Et al Widiarsa research results obtained GI cooperative learning effect on students' level of knowledge. Equation Widiarsa et al study with this research is a model of GI effect on students' level of knowledge. The study also has differences with this research. Widiarsa research subjects and others that class X SMA, while the subject of this study the high school students of class XI.

Research results Widiarsa et al (2014) also supports this research. Et al Widiarsa research results obtained GI cooperative learning effect on students' level of knowledge. Equation Widiarsa et al study with this research is a model of GI effect on students' level of knowledge. The study also has differences with this research. Widiarsa research subjects and others that class X SMA, while the subject of this study the high school students of class XI. Widiarsa et al conducted research on the subjects of biology, while this research was conducted on the subjects of geography. Model GI effect on high school students' level of knowledge to learn geography because: first, the implementation of the research done by the students in the mangrove forest village of Mojo Pemalang. Students must do research outside of school. Students are researching ways to preserve the mangrove forests and the role of communities in conservation. The learning environment outside the classroom is different from in the classroom. The difference is that learning outside the classroom is more 
contextual than in the classroom. Students look happy to see the mangrove forest in the village of Mojo. It was appropriate the opinion Sharan (2014: 130) that the model Group Investigation has the advantage of it being a class community of researchers who answered questions from a problem that comes from the surrounding environment. Second, frequent interaction when learning GI implemented. Students often interact with other students in a group to formulate questions and find answers to these questions. Students who had been quiet and shy to ask, be more frequently asked, especially the group of their friends. It happened because the student was given a place and time that is sufficient to ask the group of their friends.

This is in accordance with the opinion of Slavin (2005: 5) Group Investigation model has several advantages for students, among others "can develop relationships between groups, acceptance of classmates who are weak in the academic field, improve self-esteem, growing awareness to think, solve problems, integrate and apply the knowledge capabilities ". Third, the teacher just gave GI problems early learning. The problem that the teacher namely access to mangrove forests could only use boats and frequent flooding in the village of Mojo. It requires students to analyze problems that occur. The existence of these demands could challenge students to think critically about the problems that occur and then poured in question and determine the sub-theme of the research.

It was appropriate opinion of Huda (2011: 124) Group Investigation model has several advantages for students, among others, "the students are involved in the activities of high-level thinking, such as synthesizing, summary, hypotheses, conclusions, and present a final report". Fourth, students investigate different sub-themes. GI learning in this study membagai class into five groups. Two groups investigated the mangrove forests of the physical aspect, while the three groups menginvesigasi groups of aspects of society. Subthemes of different makes high curiosity of students. The group not only focused on the sub theme diinvestigasinya, but also have to know the sub-theme diinventigasi other groups. Students will be more comprehensive knowledge by analyzing several sub-themes. This is in accordance with the opinion of Trianto (2007: 60 ) " learning activities should involve a variety of activities and wide-ranging skills and lead students to the types of different learning resources, either inside or outside of school ". Additional findings in this study include group work seriously because their work will be evaluated by other groups and all the students are more active in learning. Such findings make GI learning in the classroom experiment goes well. Students are easier to be supervised and regulated by the teachers in each phase of learning . Each group is serious in doing its job because it will be evaluated on 
another group . Each group evaluates the clarity, attractiveness and relevance of presentation

This is in accordance with the opinion of Pintrich, et al (1991: 10 ) "extrinsic goal orientation complements intrinsic goal orientation, and concerns the degree to the which the student perceives herself to be participating in a task for s good, such as grades, rewards, performance, evaluation byothers, and competition ". Experimental class students also looks more active in learning. No more students are sleeping, playing mobile phone, or talking with friends. The opposite occurs in the control class. Some students in the control class still looks passive. This is indicated by the students were sleeping and talking with friends. Learning control class that will obviously interfere with the teacher in presenting the material and passive students who will not understand the material conveyed teacher.

This is in accordance with the opinion of Rusman (2012: 222) model of Group Investigation has advantages such as "develop student creativity, either individually or in groups and is seen as an active learning process, because more students will learn through the process of formation and creation". GI model's shortcomings in this research that not all students in the group are active in asking when the stage presentation of the results is in accordance with the opinion.Hal Sumarmi (2012: 132) that GI has the following disadvantages: (1) The GI is not supported by the results of research in particular; (2) projects often involve groups of students who can afford because students are better able to direct their own learning; (3) GI sometimes requires setting different circumstances, different material types and different teaching styles; (4) the state of the class does not always give a good physical environment for small groups as between one group with another group too close to the discussion group can not run well then interfere with each other; and (5) the success of GI models depend on the student's ability to lead a group or work independent ly.

\section{CONCLUSION}

Based on the exposure data analysis and discussion, it can be concluded that the study on environmental preservation material with Group Investigation model a positive effect on students' level of knowledge to learn geography. The average score of students' level of knowledge to learn geography experimental class is higher than the control class . This is because the learning steps GI that requires students to search for learning resources 
and analyze problems independently. Aktivias resulted in students learning geography students' level of knowledge is high.

\section{REFERENCES}

Huda, Miftahul. 2011. Cooperative Learning. Yogyakarta: Pustaka Pelajar.

Jacksen, Sherri L. 2011. Research Methode: Moduler Approach. Stamford: Cengage Learning.

Kosasih. 2007. Optimalisasi Media Pembelajaran.Jakarta : PT. Grasindo.

Mushodik. 2013. Pengaruh Model Pembelajaran Group Investigation terhadap Kemampuan Berpikir Kritis Siswa Madrasah Aliyah Negeri 6 Jakarta. Tesis tidak diterbitkan. Malang: PPS Universitas Negeri Malang.

Pintrich, R. Paul .Et al. 1991. A Manual for The Use of The Motivated Strategies for Learning Questionnaire. Ann Arbor, Michigan : National Center for Research to Improve Postsecondary Teaching and Learning.

Rusman. 2012. Model-Model Pembelajaran. Jakarta: Raja Grafindo Persada.

Sanjaya, Wina. 2006. Strategi Pembelajaran Berorientasi Standar Proses. Pendidikan”, Jakarta : Kencana Prenada Media.

Sharan dan Shlomo. 1999. Handbook of Cooperative Learning. New York: Teachers College Press.

Slavin, Robert E. 2005. Cooperative Learning: theory, research and practice

(N. Yusron. Terjemahan). London: Allymand Bacon. Buku asli diterbitkan tahun 2005.

Sumarmi. 2012. Model-Model Pembelajaran Geografi. Malang : Aditya Media Publishing.

Tan, Ivy Geok Chin. 2004. Effects of cooperative learning with group investigation on secondary students' achievement, motivation and perceptions. Singapore: National Institute of Education.

Trianto. 2007. Model-model Pembelajaran Inovatif Berorientasi Konstruktivistik. Jakarta: Prestasi Pustaka.

Ulfah, Restu. 2014. Pengaruh Model Pembelajaran Group Investigation terhadap Hasil Belajar Siswa Geografi Siswa SMA Negeri 1 Banjarbaru. Tesis tidak diterbitkan. Malang: PPS Universitas Negeri Malang.

Widiarsa, Putu Dkk. 2014. Pengaruh Penggunaan Model Pembelajaran Kooperatif Tipe Group Investigation (GI) Terhadap Motivasi Belajar Dan Pemahaman Konsep Biologi 
Siswa Sma Negeri 2 Banjar. E-Journal Program Pascasarjana Universitas Pendidikan Ganesha Program Studi Administrasi Pendidikan 5 (1): 1.

Yulianto, A dkk. 2013. Pengaruh Pembelajaran Kooperatif Tipe Group Investigation Berbasis Eksperimen Inkuiri terhadap Motivasi Belajar Siswa. Unnes Physics Education Journal, $2(2): 1$. 